\title{
Impact of Washing Process on the Physical Properties of Denim Fabric (Twill and Dobby)
}

\author{
Abdullah Al Rakib Shikder, Jabed Hossen Emon, Md. Humayun Kabir Khan, Md. Mehedi Hasan, \\ and Md. Abu Bakar Siddiquee
}

\begin{abstract}
The study was focused on investigating the impact of different washing processes (dark shade, medium shade, light shade) on various properties of denim fabric. Two different types of fabrics with twill and dobby weave constructions were produced from cotton, spandex, and polyester yarn, and different types of washing processes were applied. Dimensional stability, tensile strength, tearing strength, EPI and PPI, weight, colorfastness to rubbing, colorfastness to perspiration (acid and alkaline), and colorfastness to water was investigated and comparisons were made statistically between the before washed sample and after washed sample. It is found that the process result shows better tear and tensile strength in case of dark \& medium shade wash than light shade wash. On the other hand, weight and EPI \& PPI have shown better result for light wash than other wash. Colorfastness to rubbing, Colorfastness to water, and Colorfastness to perspiration (acid and alkaline medium) are similar. The shrinkage\% is higher especially in the weft direction of the fabric for light wash than the dark wash.
\end{abstract}

Keywords - Denim Washing, Tensile Strength, Dimensional Stability, Tear Strength, Color Fastness, EPI and PPI.

\section{INTRODUCTION}

Denim is one of the predominant clothing products in the textile field recently [1]. It is a very strong, and stiff fabric constructed with weft white yarn and warp colored yarn which are fashion trend for all classes people, all seasons, all climatic conditions and all over the world [2], [3]. The weft yarn of the denim fabric enlarges alongside the entire width of the fabric [4]. Among various finishing processes in denim garments manufacturing, washing is a significant process and it's mainly applied on denim garments to modify the appearance, size outlook, comfortability, and fashion of the garments [5].

The utmost impact is made on the wear, hygienic and mechanical properties of items by washing [6]. Due to washing, insoluble matters or other impurities from the fabric are removed and it is also performed to produce effects such as color fading with or without patchiness, crinkles, puckering, hairiness softened hand feels, and stabilize dimensions in denim garment [7], [8]. Due to after wash shrinkage of some garments, it could be purchased directly from the store or shop as per required size [9]. So, garments washing especially denim garments have become popular all

Submitted on October 27, 2021.

Published on December 02, 2021.

Abdullah Al Rakib Shikder, Department of Textile Engineering, Uttara University, Bangladesh.

Jabed Hossen Emon, Department of Textile Engineering, Uttara University, Bangladesh.

(Corresponding e-mail: jabedhossenemon ${ }^{\circledR}$ gmail.com) over the world day by day [10].

Bleach wash, stone wash, acid wash, detergent wash, silicon wash, etc are used to focusing on the finishing of denim fabric [11].

Several studies were done about the changes in physical and mechanical properties of denim fabrics in context with a PP wash, enzyme wash, bleach wash. [12], and stone \& acid wash [13]. In a study, the influence of washing (enzyme wash with stone and bleach) on the tensile strength of the denimwashed fabric were investigated [14]. In another study, the changes in tear strength, fabric weight, tensile strength, dimensional stability, and different colorfastness properties were examined with different types of washing processes [15]. By using different softeners on stretch denim fabric, dimensional stability and colorfastness properties of stretch denim fabric was also studied [16].

This paper aims to determine the impact of different shade wash (dark shade, medium shade, and light shade) on various properties of twill and dobby weave denim fabric.

\section{MATERIALS AND METHODS}

\section{A. Materials}

Two types of fabric were used for this research, one was slub stretch and another was regular poly stress denim. Slub stretch-denim composition is $99.15 \%$ cotton and $0.85 \%$ spandex. Regular poly stretch denim composition is $81 \%$ cotton, $18 \%$ polyester, $1 \%$ spandex.

\section{1) Details of Dobby regular poly stretch denim fabric}

Construction $\quad: 20 \mathrm{KWC} \times 12 \mathrm{OE}+150 \mathrm{~L}+40 \mathrm{D}(\mathrm{ACY})$ Weave : Dobby

Fiber composition : 70\% BCI Cotton, 5.7\% PCW, 23.1\% Polyester, $1.2 \%$ Spandex

$\begin{array}{ll}\text { Color } & : \text { Indigo } \\ \text { EPI X PPI } & : 136 \times 100 \\ \text { GSM } & : 313\end{array}$

2) Details of Twill slub stretch-denim fabric

Construction $\quad: 20 \mathrm{KWC} \times 12 \mathrm{OE}+150 \mathrm{~L}+40 \mathrm{D}(\mathrm{ACY})$ Weave : Dobby

Fiber Composition : 70\% BCI Cotton, 5.7\% PCW, 23.1\%

Color Polyester, $1.2 \%$ Spandex

Md. Humayun Kabir Khan, Department of Textile Engineering, Uttara University, Bangladesh.

Md. Mehedi Hasan, Department of Textile Engineering, Uttara University, Bangladesh.

Md. Abu Bakar Siddiquee, Department of Textile Engineering, Uttara University, Bangladesh. 


$\begin{array}{ll}\text { EPI X PPI } & : 136 \times 100 \\ \text { GSM } & : 313\end{array}$

B. Methods

1) Simplification of research methodology

Collection of finished fabrics from fabric store $\downarrow$

Cutting the finished fabric $\left(36^{*} 36\right)$ inches and makes the 6tube leg for the washing process.

$$
\downarrow
$$

Determination of Physical properties and colorfastness properties before wash

$$
\downarrow
$$

Washing the fabrics (Dark Wash, Medium Wash, Light Wash) $\downarrow$

Determination of Physical properties and colorfastness properties after wash

Data analysis and discussion

\section{2) Washing recipe of Dark, Medium, and Light Shade}

\section{1) Recipe for Dark Shade Wash}

The detailed recipe which has been used for washing dark shade is given in Table I.

\begin{tabular}{cccccc}
\multicolumn{6}{c}{ TABLE I: RECIPE FOR DARK WASH } \\
\hline $\begin{array}{c}\text { Product/Chemical } \\
\text { Name }\end{array}$ & Process & Tem $^{\circ} \dot{\mathrm{C}}$ & Time & GPL & M:R \\
\hline $\begin{array}{c}\text { Anti-back staining } \\
\text { agent (NTM) }\end{array}$ & -- & 50 & 5 & 1 & $1: 15$ \\
$\begin{array}{c}\text { Desizing agent } \\
\text { Alpha-amylase) }\end{array}$ & Desize & 50 & 20 & 1 & \\
$\begin{array}{c}\text { Acetic acid(pH- } \\
\text { 5.5) }\end{array}$ & Rinse & 50 & 3 & 0.5 & \\
& $\begin{array}{c}\text { Hydro } \\
\text { Dryer(stem) }\end{array}$ & - & 5 & - & \\
\hline
\end{tabular}

\section{2) Recipe for Medium Shade Wash}

The detailed recipe which has been used for washing medium shade is given in Table II.

\begin{tabular}{|c|c|c|c|c|c|}
\hline $\begin{array}{c}\text { Product/Chemical } \\
\text { Name } \\
\end{array}$ & Process & $\operatorname{Tem}^{\circ} \dot{\mathrm{C}}$ & Time & GPL & $\mathrm{M}: \mathrm{R}$ \\
\hline $\begin{array}{c}\text { Desize agent } \\
\text { (alpha-amylase) }\end{array}$ & Desize & 50 & 15 & 1 & $1: 15$ \\
\hline $\begin{array}{l}\text { Anti-back staining } \\
\text { agent (NTM) }\end{array}$ & -- & 50 & -- & 1 & \\
\hline Water & Rinse & RT & 3 & & \\
\hline Neutral enzyme & Enzyme & 45 & 45 & 1 & \\
\hline $\begin{array}{l}\text { Anti-back staining } \\
\text { agent (NTM) }\end{array}$ & -- & 45 & -- & 1 & \\
\hline Water & Rinse & $\mathrm{RT}$ & 2 & & \\
\hline $\begin{array}{l}\text { Bleach (Calcium } \\
\text { hypochlorite) }\end{array}$ & Bleach & 50 & 2 & 2 & \\
\hline Water & Rinse & $\mathrm{RT}$ & 3 & & \\
\hline Neutralizing Agent & Neutral & 50 & 10 & 0.5 & \\
\hline $\begin{array}{l}\text { Anti-back staining } \\
\text { agent (NTM) }\end{array}$ & -- & 50 & -- & 1 & \\
\hline Water & Rinse & RT & $\begin{array}{c}3 \\
\text { To }\end{array}$ & & \\
\hline \multirow[t]{3}{*}{ Acid (pH 5.5) } & Rinse & RT & $\begin{array}{c}\text { adjust } \\
\mathrm{pH}\end{array}$ & & \\
\hline & Hydro & -- & 5 & -- & \\
\hline & $\begin{array}{l}\text { Dryer } \\
\text { (stem) }\end{array}$ & 70 & 30 & -- & \\
\hline
\end{tabular}

\section{TABLE II: RECIPE FOR MEDIUM WASH}

\section{3) Recipe for Light Shade Wash}

The detailed recipe which has been used for washing light shade is given in Table III.

\begin{tabular}{|c|c|c|c|c|c|}
\hline $\begin{array}{c}\text { Product/Chemical } \\
\text { Name }\end{array}$ & Process & $\operatorname{Tem}^{\circ} \dot{\mathrm{C}}$ & Time & GPL & M:R \\
\hline $\begin{array}{l}\text { Desizing agent } \\
\text { (alpha-amylase) }\end{array}$ & Desize & 50 & 15 & 1 & $1: 15$ \\
\hline $\begin{array}{l}\text { Anti-back staining } \\
\text { agent (NTM) }\end{array}$ & -- & 50 & -- & 1 & \\
\hline Water & Rinse & RT & 3 & 1 & \\
\hline Neutral enzyme & Enzyme & 45 & 45 & 1 & \\
\hline $\begin{array}{l}\text { Anti-back staining } \\
\text { agent (NTM) }\end{array}$ & -- & 45 & -- & 1 & \\
\hline Water & Rinse & RT & 2 & 1 & \\
\hline $\begin{array}{l}\text { Bleach (Calcium } \\
\text { hypochlorite) }\end{array}$ & Bleach & 50 & 3 & 1 & \\
\hline Water & Rinse & RT & 3 & & \\
\hline $\begin{array}{l}\text { Neutralizing } \\
\text { Agent }\end{array}$ & Neutral & 50 & 10 & 0.5 & \\
\hline $\begin{array}{l}\text { Anti-back staining } \\
\text { agent (NTM) }\end{array}$ & -- & 50 & -- & 1 & \\
\hline Water & Rinse & RT & 3 & & \\
\hline \multirow[t]{3}{*}{ Acid (pH 5.5) } & Rinse & RT & $\begin{array}{c}\text { To } \\
\text { adjust } \\
\text { pH }\end{array}$ & 0.5 & \\
\hline & Hydro & -- & 5 & -- & \\
\hline & Dryer(stem) & 70 & 30 & -- & \\
\hline
\end{tabular}

\section{TABLE III: RECIPE FOR LIGHT WASH}

\section{3) Testing Instrument (physical and chemical test)}

Many testing instruments have been used for the testing. Below is the list of instruments and their name accordingly.

a. Dimensional stability: $35 \times 35 \mathrm{~cm}$ (template);

b. Tear strength test: Tear strength tester;

c. GSM measurement: GSM cutter;

d. EPI and PPI Measurement: Counting glass;

e. Fastness to water and perspiration test: Per spirometer;

f. Rubbing test: Crock meter;

g. For assessing color staining: Greyscale ISO 105 - A03; h. Tensile test: Tensile machine.

4) Test Methods

i. Color Fastness Tests
(a) PH Test (ISO-3071);
(b) Color Fastness to Perspiration (ISO 105-E04);
(c) Color Fastness to Water (ISO 105-E01) ;
(d) Color Fastness to Rubbing Color (ISO 105-X12).

\section{ii. Physical Properties Tests}

(a) Dimensional stability (ISO-6330);

(b) Yarn density (EPI and PPI);

(c) Mass per unit area (ISO 3803);

(d) Tear Strength (ISO 139347-2);

(e) Tensile Strength (ISO 13934-2).

\section{RESUlts AND DiscUSSION}

\section{A. Effect of Different Wash on Colorfastness to Water}

Below is the table for the detailed test result for colorfastness to water at details for all used washes. 
TABLE IV: EFFECT OF DIFFERENT WASH ON COLORFASTNESS TO WATER

\begin{tabular}{|c|c|c|c|c|}
\hline \multirow[b]{2}{*}{$\begin{array}{l}\text { Different types } \\
\text { of wash }\end{array}$} & \multicolumn{2}{|c|}{ Twill fabric } & \multicolumn{2}{|c|}{ Dobby fabric } \\
\hline & $\begin{array}{c}\text { Grade } \\
\text { (Color } \\
\text { Change) }\end{array}$ & $\begin{array}{c}\text { Grade } \\
\text { (Color } \\
\text { Staining) }\end{array}$ & $\begin{array}{c}\text { Grade } \\
\text { (Color } \\
\text { Change) }\end{array}$ & $\begin{array}{c}\text { Grade } \\
\text { (Color } \\
\text { Staining) }\end{array}$ \\
\hline Before wash & 4 & 4 & 4 & $4-5$ \\
\hline Dark wash & 4 & 4 & 4 & $4-5$ \\
\hline Medium wash & 4 & 4 & 4 & $4-5$ \\
\hline Light wash & 4 & $4-5$ & 4 & $4-5$ \\
\hline
\end{tabular}

Table IV illustrates the consequence of colorfastness to the water of twill and dobby denim fabric for different wash (dark, medium \& light wash). Color change and color staining grade was almost unchanged for different wash. For twill fabric, an inconsiderable change was found in the color staining and slightly improved the color fastness compared to the before and after wash samples. For dobby fabric, there is no significant changes were found in the color staining.

\section{B. Effect of Different Wash Shade on Fabric Weight}

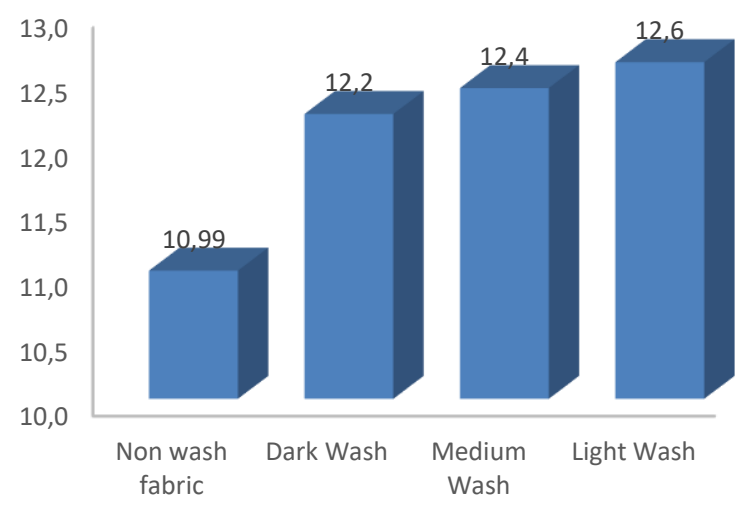

Fig. 1. Changes in weight after wash (Twill Fabric).

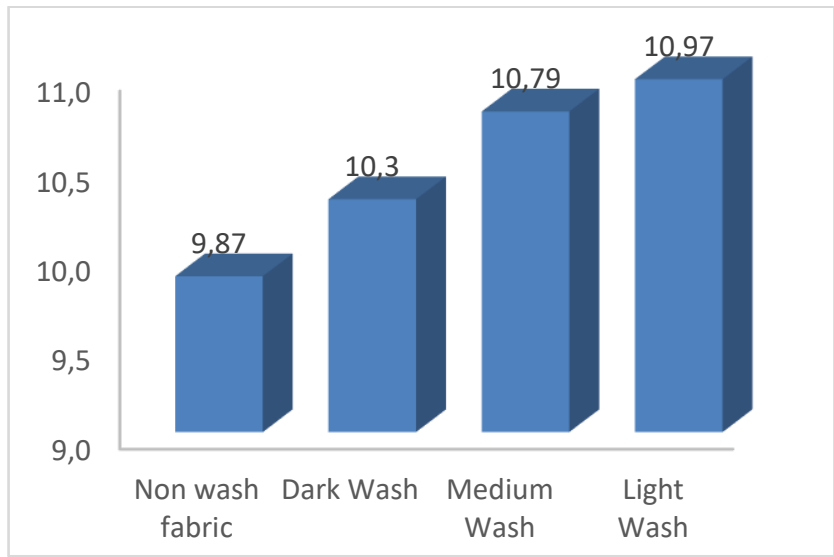

Fig. 2. Changes in weight after wash (Dobby fabric).

Fig. 1 and Fig. 2 show that the weight of before wash denim fabric was $10.99 \mathrm{Oz} / \mathrm{yd}^{2}$ and it increased upon dark wash, medium wash \& light wash and values are 12.2, 12.4 and 12.6. That means samples gain more weight during light wash than dark wash and medium wash. So, we can say that different wash effect can plays a significant change in fabric weight as well as GSM.

\section{Effect of Different Wash on Colorfastness to Rubbing}

Colorfastness to rubbing has been affected significantly due to the wash effect. The below table is stated for details.
TABLE V: EFFECT OF DIFFERENT WASH ON CF TO RUBBING

\begin{tabular}{ccccc}
\hline \multirow{2}{*}{$\begin{array}{c}\text { Different types } \\
\text { of wash }\end{array}$} & \multicolumn{2}{c}{ Twill fabric } & \multicolumn{2}{c}{ Dobby fabric } \\
\cline { 2 - 5 } & $\begin{array}{c}\text { Grade } \\
\text { Rubbing) }\end{array}$ & $\begin{array}{c}\text { Grade } \\
\text { (Wet } \\
\text { Rubbing) }\end{array}$ & $\begin{array}{c}\text { Grade } \\
\text { (Dry } \\
\text { Rubbing) }\end{array}$ & $\begin{array}{c}\text { Grade } \\
\text { (Wet } \\
\text { Rubbing) }\end{array}$ \\
\hline Before wash & 3 & 1 & 4 & $1-2$ \\
Dark wash & 4 & $1-2$ & 4 & $1-2$ \\
Medium wash & $4-5$ & $1-2$ & $4-5$ & $1-2$ \\
Light wash & $4-5$ & 3 & $4-5$ & $2-3$ \\
\hline
\end{tabular}

Table $\mathrm{V}$ represents about the result of color fastness to rubbing of twill and dobby denim fabric for dark wash, medium wash \& light wash. It is clear that each wash shows excellent color fastness to rubbing both in dry and wet state because color fastness to rubbing was developed significantly after the treatment. The color grade of dry rubbing was relatively better in light wash \& medium wash for both twill $\&$ dobby fabric and light wash was shown better color grade for wet rubbing than dark and medium wash.

\section{Effect of Different Wash on Tearing Strength}

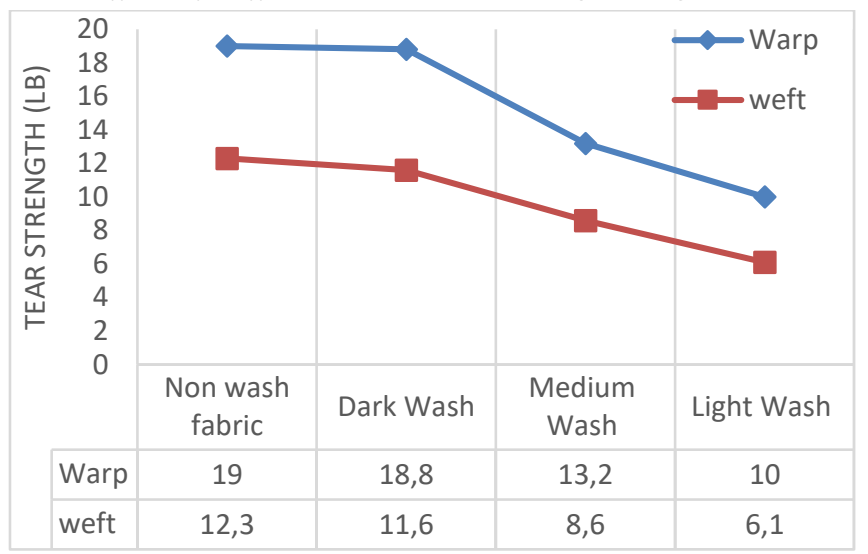

Fig. 3. Changes in tear strength after wash (Twill Fabric).

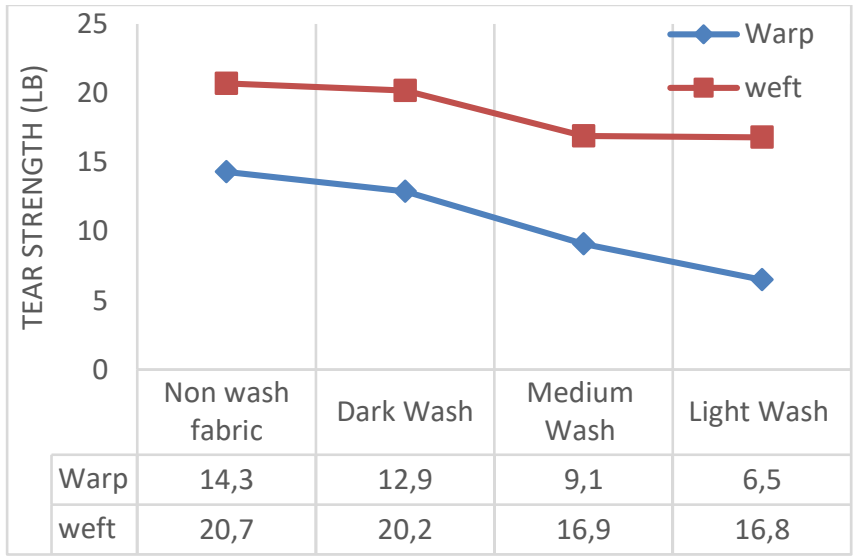

Fig. 4. Changes in tear strength after wash (Dobby Fabric).

Fig. 3 and Fig. 4 represent about the effect of washing process for tear strength of twill and dobby denim fabric in the warp and weft way direction. we see that tearing strength changes drastically with washing and it decreases in both way (warp and weft). Light wash sample was very much affected in both direction of twill fabric and dobby fabric. On the other hand, tear strength of dark washed sample is much better than other samples in both twill fabric as well as dobby fabric. So dark wash is more suitable in denim washing. 


\section{E. Effect of Different Wash on Tensile Strength}

Testing of samples was done after washing. Then, the result has been put on the graph and found below two graphs which represents tensile strength effect of the fabrics.

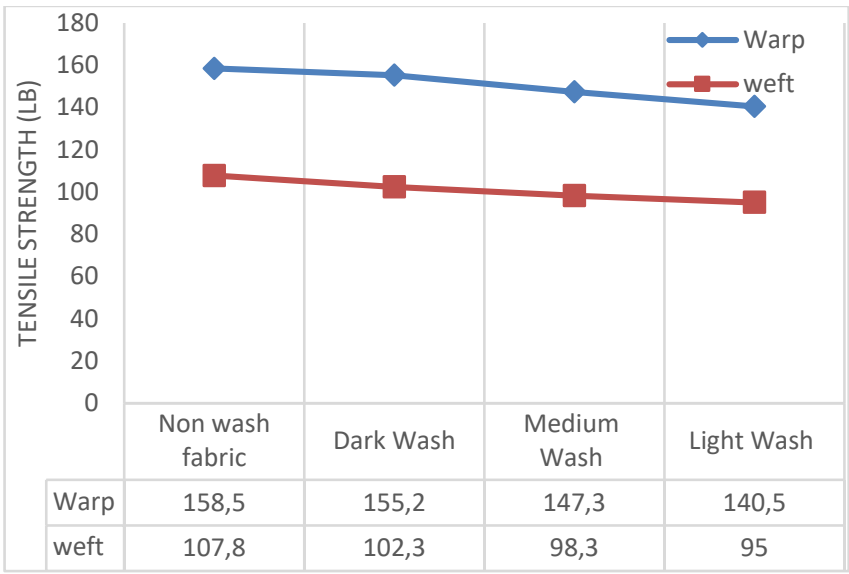

Fig. 5. Changes in tensile strength after wash (Twill Fabric).

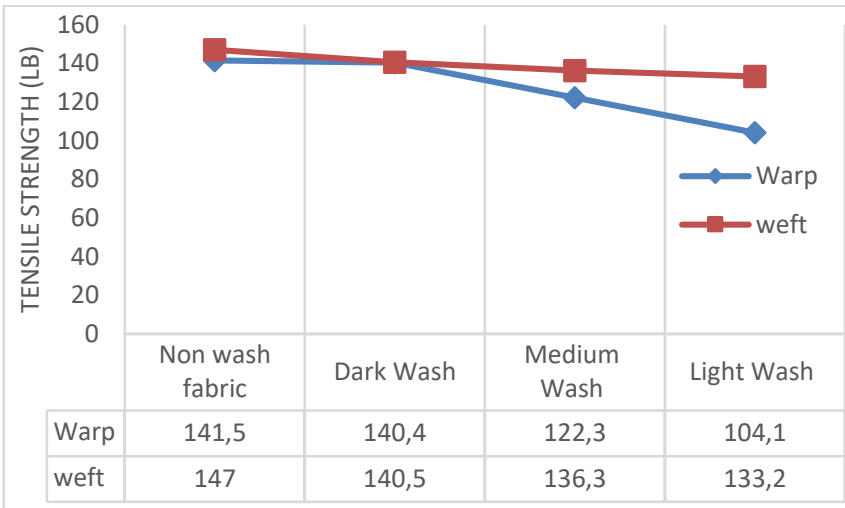

Fig. 6. Changes in tensile strength after wash (Dobby Fabric).

All the washes influence adversely on to the samples. Fig. 5 and Fig. 6 represent about the effect of washing process for tensile strength of twill and dobby denim fabric in the warp and weft way direction. Light wash sample shows the lowest result. On the other hand, tensile strength of dark washed sample is much better than other samples in both twill fabric as well as dobby fabric. So, light wash and medium wash should avoid in denim washing.

\section{F. Dimensional Stability Effect on Washed Fabrics}

TABLE VI: DimENSIONAL STABILITY EFFECT ON WASHED FABRICS

\begin{tabular}{ccccc}
\hline Different & \multicolumn{2}{c}{ Twill fabric } & \multicolumn{2}{c}{ Dobby fabric } \\
\cline { 2 - 5 } types of wash & Warp & Weft & Warp & Weft \\
\hline Before wash & 0.0 & 0.0 & 0.0 & 0.0 \\
Dark wash & -2.28 & -5.71 & -1.14 & -9.42 \\
Medium wash & -3.14 & -7.14 & -1.42 & -12.57 \\
Light wash & -3.14 & -8.28 & -2.00 & -13.14 \\
\hline
\end{tabular}

Table VI illustrates the consequence of dimensional stability of twill and dobby denim fabric for different wash (dark, medium \& light wash). To inspect the variation in dimensional stability, the shrinkage of before and after washed samples were evaluated and got a little bit of change was found in warp direction but weft-wise shrinkage is greater for both fabrics. In both direction, light wash has shown better results compared to others wash.

\section{G. Effect of Different Wash on EPI and PPI}

After washing and testing of samples, the result has been put on the graph and found below two graphs which represent the effect of different wash on EPI and PPI.

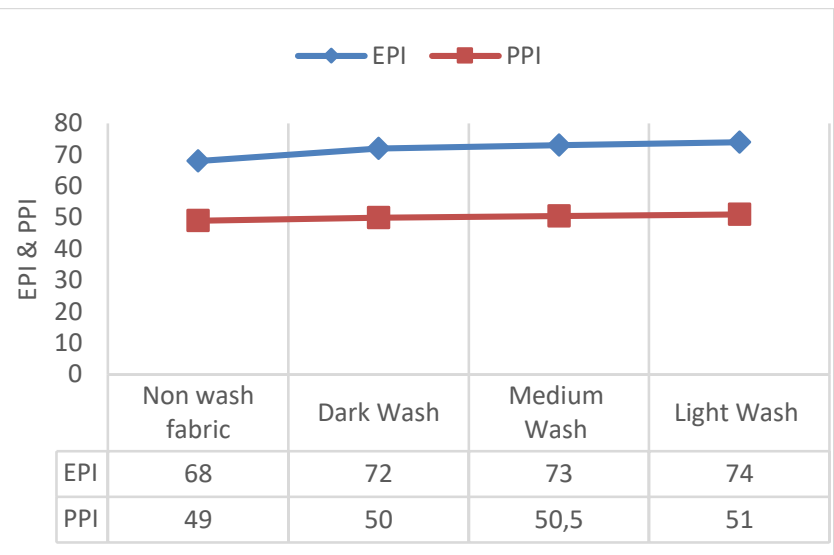

Fig. 7. Changes in EPI \& PPI after wash (Twill Fabric).

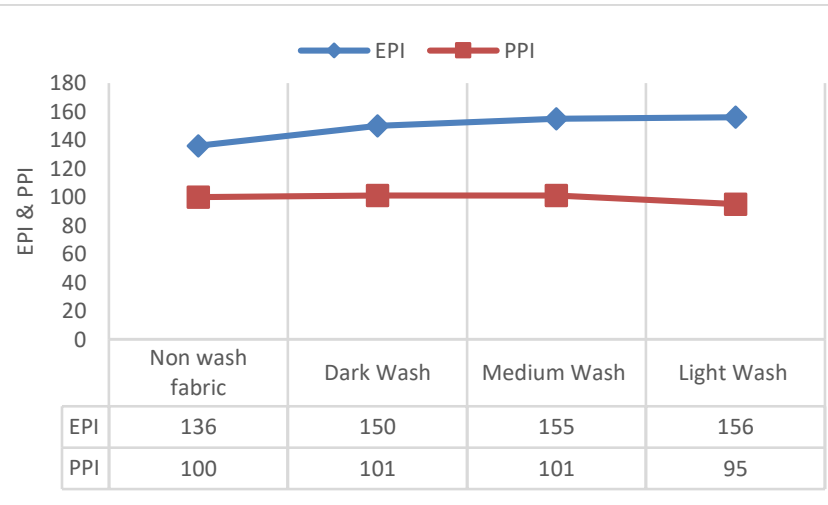

Fig. 8. Changes in EPI \& PPI after wash (Dobby Fabric).

Here in Fig. 7 and Fig. 8 vertical axis indicate the EPI \& PPI of the fabrics \& horizontal axis indicate different washing process of denim fabrics. We have got 68 EPI \& 49 PPI (Twill fabric) and 136 EPI \& 100 PPI (Dobby fabric) for before wash fabric. After washing we have got the lowest EPI \& PPI for dark wash in both direction (warp \& weft) of twill fabric and although, dark wash shows the lowest EPI in warp direction \& light wash shows the lowest PPI in weft direction.

\section{H. Effect of Different Wash on Colorfastness to Perspiration}

\section{1) Colorfastness to perspiration (Acid)}

There were no significant changes in the result that was found after the perspiration test at acid is given in Table VII.

TABLE VII: EFFECT OF DIFFERENT WASH ON COLORFASTNESS TO PERSPIRATION (ACID)

\begin{tabular}{|c|c|c|c|c|}
\hline \multirow[b]{2}{*}{$\begin{array}{c}\text { Different types } \\
\text { of wash }\end{array}$} & \multicolumn{2}{|c|}{ Twill fabric } & \multicolumn{2}{|c|}{ Dobby fabric } \\
\hline & $\begin{array}{c}\text { Grade } \\
\text { (Color } \\
\text { Change) }\end{array}$ & $\begin{array}{c}\text { Grade } \\
\text { (Color } \\
\text { Staining) }\end{array}$ & $\begin{array}{c}\text { Grade } \\
\text { (Color } \\
\text { Change) }\end{array}$ & $\begin{array}{c}\text { Grade } \\
\text { (Color } \\
\text { Staining) }\end{array}$ \\
\hline Before wash & 4 & 4 & 4 & $4-5$ \\
\hline Dark wash & 4 & 4 & 4 & $4-5$ \\
\hline Medium wash & 4 & 4 & 4 & $4-5$ \\
\hline Light wash & 4 & $4-5$ & 4 & $4-5$ \\
\hline
\end{tabular}




\section{2) Colorfastness to perspiration (Alkaline)}

There were no significant changes in the result that was found after the perspiration test at alkaline is given in Table VIII.

TABLE VIII: EFFECT OF DIFFERENT WASH ON COLORFASTNESS TO PERSPIRATION (ALKALINE)

\begin{tabular}{|c|c|c|c|c|}
\hline & \multicolumn{4}{|c|}{ PERSPIRATION (ALKALINE) } \\
\hline \multirow[b]{2}{*}{$\begin{array}{l}\text { Different types } \\
\text { of wash }\end{array}$} & \multicolumn{2}{|c|}{ Twill fabric } & \multicolumn{2}{|c|}{ Dobby fabric } \\
\hline & $\begin{array}{c}\text { Grade } \\
\text { (Color } \\
\text { Change) }\end{array}$ & $\begin{array}{c}\text { Grade } \\
\text { (Color } \\
\text { Staining) }\end{array}$ & $\begin{array}{c}\text { Grade } \\
\text { (Color } \\
\text { Change) }\end{array}$ & $\begin{array}{c}\text { Grade } \\
\text { (Color } \\
\text { Staining) }\end{array}$ \\
\hline Before wash & 4 & 4 & 4 & $4-5$ \\
\hline Dark wash & 4 & 4 & 4 & $4-5$ \\
\hline Medium wash & 4 & 4 & 4 & $4-5$ \\
\hline Light wash & 4 & $4-5$ & 4 & $4-5$ \\
\hline
\end{tabular}

Table VII and Table VIII clear the results that no significant changes occurred in colorfastness to perspiration for both Acidic and Alkaline medium of each washed samples of the fabrics. For twill fabric, a slight change in the color staining grade of light wash was observed and slightly improved the color fastness compared to the before wash sample and other wash samples. For dobby fabric, there is no significant changes were found in the color staining.

\section{CONCLUSIONS}

In this study, fabric weight, tear strength, tensile strength, EPI and PPI, various colorfastness properties, and dimensional stability were analyzed by applying different wash shade on denim fabric.

The weight of both denim fabrics incremented consistently after applying different kinds of shade wash and showed the highest value for the light wash. The tear strength and tensile strength of both fabrics are decreased in both directions after wash. The EPI and PPI are also decreased. Light washed sample was shown better grade than other washed sample for dry and wet rubbing. The grade for colorfastness to perspiration (acid and alkaline) and colorfastness to water were remain unchanged with different types of wash. The dimensional stability of each sample was also changed significantly by applying different wash shade. The highest shrinkage has occurred in the weft direction for the light wash.

From this study, it is found out that light wash and dark wash have a great influence on different properties of denim fabric.

\section{REFERENCES}

[1] Kan CW. Effect of enzyme washing on the tensile property of denim fabric. Adv Mat Res. 2014; 933:175-178. Trans Tech Publications Ltd. https://doi.org/10.4028/www.scientific.net/AMR.933.175.

[2] Razzaque MA. Garment \& Textile Merchandising. Popular Publications, Dhaka. 2004

[3] Kashem M. A. Apparel Merchandising, 1st edn. Lucky-One Traders, Dhaka, Bangladesh, 2008, pp. 69-71.

[4] Kan CW, Yuen CW. Effect of atmospheric pressure plasma treatment on the desizing and subsequent colour fading process of cotton denim fabric. Color. Technol. 2012; Oct;128(5):356-63. https://doi.org/10.1111/j.1478-4408.2012.00388.x.

[5] Zareen A., Akter F., Sarker S., Ferdous R., Islam M., Sultana S. et. al. Washing Effects Investigation on Physical Properties of Denim Fabric. North American Academic Research, 2019;2(7);209-217. https://twasp.info/journal/archive/209-217.pdf.
[6] Jucienè M, Dobilaitė V, Kazlauskaitė G. Influence of industrial washing on denim properties. Mater Sci. 2006;12(4):355.https://www.matsc.ktu.lt/index.php/MatSc/article/vie w/26475/13 588

[7] Yildirim N, Üstüntağ S, Örtlek HG. The Effects of Washing Treatments on Physical Properties of Denim Fabrics. Tekst. ve Muhendis, 2014; 21:16-29.

http://www.tekstilvemuhendis.org.tr/showpublish.php?pubid=410\&ty pe=full.

[8] Celik HI, Kaynak HK. An investigation on the effect of elastane draw ratio on air permeability of denim bi-stretch denim fabrics. IOP Conf. Ser.: Mater. Sci. Eng., 2017;254(8):2007.

https://iopscience.iop.org/article/10.1088/1757899X/254/8/082007/meta

[9] M.S. Azam, M.S. Saleh \& K.A. Nafiz. An introductory knowledge about garments manufacturing technology (Dhaka: Books Fair Publication), 2009.

[10] Khan MM, Mondal MI, Uddin MZ. Effect of bleach wash on the physical and mechanical properties of denim Garments Int. Conf. Mech. Eng., 2011;3:1-6.

https://me.buet.ac.bd/icme/icme2011/Proceedings/PDF/ICME\%2011FL-022.pdf

[11] Shenai VA. Chemistry of Organic Textile Chemicals. Sevak Publications, Bombai. 1995:127.

[12] Ansari IZ. Changes in mechanical properties of denim due to different washing processes. Int Res J Eng Technol, 2017;4(10):1424-7. https://www.academia.edu/download/54947158/IRJETV4I10261.pdf.

[13] Ansari IZ. Impact of stone wash and acid wash on the physical properties of denim. Int. J. Eng. Res., 2017;6(12):499501.http://dx.doi.org/10.5958/2319-6890.2017.00073.3.

[14] El-Dessouki HA. Effect of different washing methods on mechanical properties of egyptian denim fabrics. Int. J. Des., 2015 Jul 1;5(3):1099 107.https://dx.doi.org/10.21608/idj.2015.101517.

[15] Hasan MZ, Asif AA, Razzaque A, Hasan MR, Sur S, Faruque MO. An Experimental Investigation of Different Washing Processes on Various Properties of Stretch Denim Fabric. J. mater. sci. chem. eng., 2021 Jan 19;9(01):1.https://www.scirp.org/html/1-1740881_106600.htm.

[16] Hosen F, Hasan MZ, Asif AA. Effect of Different Softeners on Dimensional Stability and Color Fastness Properties of Stretch Denim Fabric. Advances Appl. Sci., 2020 Nov 11;5(4):112. http://www.applsci.org/article/109/10.11648.j.aas.20200504.13. 